\title{
骨材-モルタル平面モデルを用いたコンクリートの変形挙動

\author{
MECHANICAL AND FAILURE BEHAVIOR OF PLANE MODELS COMPOSED OF \\ AGGREGATES AND MORTAR
}

\author{
梶川康男*・橘吉宏**.吉田博*** \\ By Yasuo KAJIKAWA, Yoshihiro TACHIBANA and Hiroshi YOSHIDA
}

\begin{abstract}
Mechanical behavior and failure properties of plane models composed of aggregates and mortar are studied experimentally and theoretically using an elasto-plastic finite element method. The plane models idealized concrete, the shape and arrangement of its aggregates being varied. In theoretical analysis, the interface between mortar and aggregate is represented by joint element. The constitutive equations of the mortar and interface between mortar and aggregate are based on the plastic flow theory to present the influence of dilatancy. The aggregate is assumed a linear-elastic material. Using these analytical model, it is found that the theoretical analysis and the actual behavior of biaxial loading tests coincide with each other. From the results of this successful analysis, it may be concluded that the shape of aggregates relates with the hydrostatic pressure and the arrangement with the deviatric stress, respectively.
\end{abstract}

\section{1. まえがき}

コンクリートは複雑な挙動を示す複合材料である.そ の構造レベルとしてまず, 巨視レベルではコンクリート は擬似均質であるとみなされ，中間レベルでは空隙，ひ びわれ，介在物を含む不均一なものとみなされ，微小レ ベルでは水粒子やセメントゲルで論ぜられている1”. ど のレベルに着目してもその複合材料としての性質がまだ 明らかにされていないという理由で, 実験的研究が主に 行われている.

一方, 解析的研究に関しては, RC 構造の有限要素解 析の発展に伴い, 巨視レベルで扱われる構成式の研究が 進められており，その代表的なものとして等価一軸ひず みモデル, 塑性理論に基づくモデル, また最近では応力 履歴を考慮した前川・岡村のモデル2)などが挙げられ る.

そこで本研究ではまず，コンクリートを骨材とモル夕 ルの二相材料とみなした骨材-モルタル平面モデルを用

* 正会員 工博 金沢大学助教授 工学部土木工学科 ( $\overline{7} 920$ 金沢市小立野 2-40-20)

**正会員 工修 川田工業(株)技術本部研究室 （元 114 北区滝野川1-3-11）

*** 正会員 工博 金沢大学教授 工学部土木工学科 ( ₹ 920 金沢市小立野 2-40-20)
い,すなわち中間レベルに着目した平面応力弾塑性有限 要素解析により, 骨材とモルタルの界面特性 (強度, 形 状，配置など）がコンクリートの強度および変形特性に いかに影響するかを調べた。この種の研究により不均一 性をもったコンクリートに対する解析が可能となり, そ の不均一性によりコンクリート構造物の強度のばらつき が表現できることになるであろう。このような手法は宮

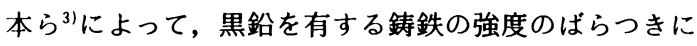
ついて報告されている.

1972 年に Buyukozturk と Nilson ${ }^{4)}$ はコンクリートを 骨材-モルタル平面モデルに理想化して，その強度は一 軸圧縮より二軸圧縮の方が強くなることを予測した。し かし, この研究が行われた時期は, コンクリートの構成 式や破壊規準についてまだ十分な研究がされておらず, その解析は弾性有限要素解析にモール・クーロン破壊規 準を取り入れたものであった。本研究では解析による骨 材一モルタル平面モデルが塑性域まで含めて，より実際 の挙動に近いものとなるようにモルタルの構成式には塑 性理論に基づいたChen らのモデル5)を用いた。塑性理 論に基づく構成式の特幑は, コンクリートや土などのよ うに粒状体を含む材料において塑性域でみられるせん断 によるダイレイタンシーの効果を表現できることにあ る. モルタルと骨材との界面には Goodman らのジョイ 
ント要素 ${ }^{6}$ を用いたが，実際のコンクリート中でのモル タルと骨材の界面でもダイレイタンシーによる体積膨張 が考えられ，本研究でも，ダイレイタンシーを考慮に入 れたモデル化を行った.

このような骨材-モルタル平面モデルのモデル化によ り，骨材の形と配置でいかにそれらの挙動が変化するの かを調べた。その骨材パターンとして，4 ケースを用い て一軸圧縮載荷と二軸圧縮比例載荷の数値実験を行い, それらの変形特性と破壊特性について考察を加えた。

これらの数值解析結果は，まず実際の挙動を満足しな ければコンクリートの理想化として用いることができな い. そこで, 本研究では骨材-モルタル平面モデルの 1 つのケースについて一軸王縮載荷試験および二軸圧縮載 荷試験を行い, 解析結果と実験結果との比較を行うこと により，本研究で用いた骨材-モルタル平面モデルの妥 当性を検討した。

\section{2. 骨材一モルタル平面モデルの弾塑性有限要 素解析}

ここでは，モルタルと骨材のモデル化とその界面の取 扱い方法について述へ，解析方法についても説明する.

\section{（1）解析および有限要秦分割}

解析に用いた骨材一モルタル平面モデルは，骨材の形 と配置による影響をみるために Fig. 1 の 4 ケース（丸い 骨材で, 半径が大きく粗な場合, 半径が小さく密な場合, 隅角部を有する骨材で, その大きさがほぼ等しい場合, 大小混ざっている場合）について考え，解析は対称性を 考虑して全体平面モデルの $1 / 4$ を行った。各骨材-モル タル平面モデルの骨材含有率は $48 \%$ と一定にし, 厚さ は $5 \mathrm{~cm}$, Fig. 1 は $1 / 4$ 要素であるので実際の一辺は 20

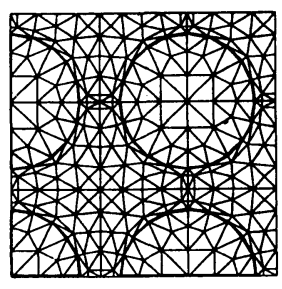

Case 1

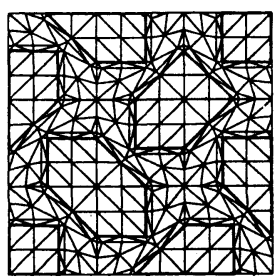

Case 3

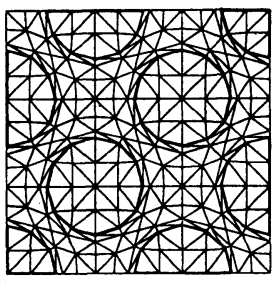

Case 2

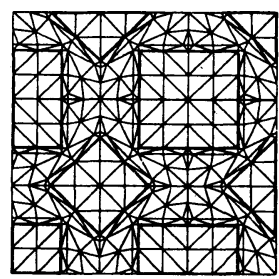

Case 4
Fig. 1 Finite Element of Plane Models Composed of Mortar and Aggregates. $\mathrm{cm}$ である. なお, 節点数と要素分割数については Table 1 に示した.

（2）モルタルと骨材のモデル化

モルタルの塑性域での構成式には，塑性理論に基づい たChenらのモデル5)を用いた. Chen らのモデルは均 質なコンクリートの構成式として考案されたものである が，コンクリートとモルタルの破壊曲面は類似している との報告")から，本研究ではこれをモルタルにも適用し た. 塑性理論による構成式は，応力の関数である降伏関 数と塑性ポテンシャルが存在し, 塑性ポテンシャルに塑 性ひずみ増分べクトルが直交するという仮定を基礎とし ている.しかしながら, その構成式は, 実際のコンクリー トや土などで不安定現象の 1 つとして観察されるひずみ 軟化は表現できず，適用範囲はひずみ硬化および加工硬 化塑性体に限られる．Chen らのモデルでは，材料を等 方性体であると仮定し, 塑性ポテンシャルを降伏関数と みなした Associated Flow Ruleにより構成式を誘導し ている.

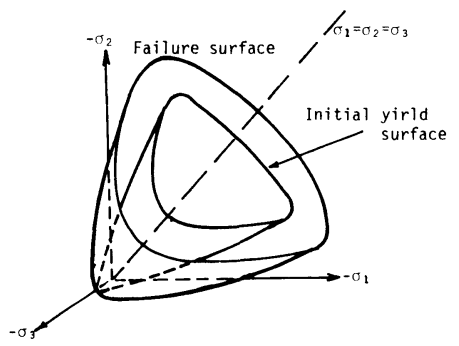

Fig. 2 Failure and Initial Yield Surfaces in ThreeDimensional Stress Space (Ref. 8).

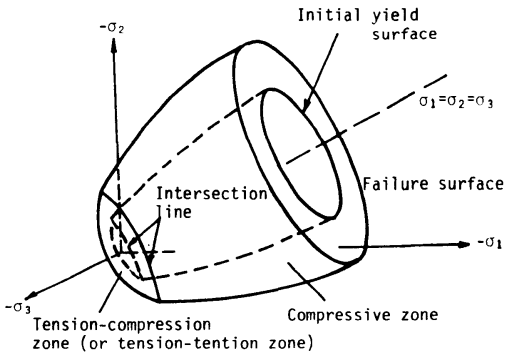

Fig. 3 Failure and Initial Yield Surfaces According to the Model due to Chen et al. (Ref. 8).

Table 1 Number of Elements and Nodal Points.

\begin{tabular}{|c|c|c|c|c|}
\hline & Number of & $\begin{array}{c}\text { Number of } \\
\text { Elements for } \\
\text { Mortar }\end{array}$ & $\begin{array}{c}\text { Number of } \\
\text { Elements for } \\
\text { Aggregates }\end{array}$ & $\begin{array}{c}\text { Number of } \\
\text { Joint } \\
\text { Elements }\end{array}$ \\
\hline Case 1 & 313 & 329 & 135 & 45 \\
\hline Case 2 & 289 & 270 & 126 & 54 \\
\hline Case 3 & 316 & 342 & 108 & 54 \\
\hline Case 4 & 316 & 342 & 108 & 54 \\
\hline
\end{tabular}


一般に, 三次元主応力空間中でのコンクリートの初期 降伏曲面と破壊曲面は Fig. 2 のようになり，このような 形の初期降伏曲面と破壊曲面とをほぼ満足するには, そ れぞれ，最低 5 個のパラメーターを必要とし，その特性 試験がたいへん困難なものとなる。本研究で用いた Chen らのモデルでは, 初期降伏曲面および破壊曲面は Fig. 3 に示すような形をしており, 一軸圧縮試験, 引張 試験, 等二軸告縮試験により，初期降伏曲面と破壊曲面 に対するパラメーターが決定できる．また，コンクリー 卜の特性が大きく異なる圧縮域と引張域とで別々の規準 を設けており，パラメーターが少ないわりに降伏曲面お よび破壊曲面をよく近似するといわれている，具体的に は降伏関数 $f$ は次式で表わされる.

圧縮一王縮域

$$
f=\frac{J_{2}+\frac{1}{3} A_{c} I_{1}}{1-\frac{1}{3} B_{c} I_{1}}=\left\{\tau\left(\bar{\varepsilon}_{p}\right)\right\}^{2}
$$

引張-引張域, 引張-王縮域

$$
f=\frac{J_{2}-\frac{1}{6} I_{1}^{2}+\frac{1}{3} A_{t} I_{1}}{1-\frac{1}{3} B_{t} I_{1}}=\left\{\tau\left(\bar{\varepsilon}_{p}\right)\right\}^{2}
$$

ここに， $J_{2}$ は偏差応力第 2 不変量であり， $I_{1}$ は応力第 1 不変量であり, また $A_{c}, B_{c}, A_{t}, B_{t}$ は初期降伏曲面 と破壊曲面に対するパラメーターより決定される定数で ある. そして,ここでは $\tau$ を相当応力ということにする. なお, 式(1)の不変量において二次元成分のみを考える ことによって, 二次元問題を取り扱うことができる.

この降伏関数を塑性理論から導かれる以下の弾塑性増 分構成式に代入して, 増分応力ーひずみ関係マトリック スが得られる ${ }^{8)}$.

$$
\{d \sigma\}=\left([D]-\frac{[D]\left\{\frac{\partial f}{\partial \sigma}\right\}\left\{\frac{\partial f}{\partial \sigma}\right\}^{T}[D]}{A+\left\{\frac{\partial f}{\partial \sigma}\right\}^{T}[D]\left\{\frac{\partial f}{\partial \sigma}\right\}}\right) \times\{d \varepsilon\}
$$

ここで, $\sigma$ は応力ベクトル, $\varepsilon$ はひずみベクトル, $[D]$ は弾性応力ーひずみ関係マトリックスである，また，

$$
\begin{aligned}
& A=2 \tau \frac{d \tau}{d \bar{\varepsilon}_{p}} \sqrt{\left\{\frac{\partial f}{\partial \sigma}\right\}^{T}\left\{\frac{\partial f}{\partial \sigma}\right\}} \\
& \bar{\varepsilon}_{p}=\int \sqrt{d \varepsilon_{i j}^{\rho} d \varepsilon_{i j}^{p}} .
\end{aligned}
$$

$\tau-\bar{\varepsilon}_{p}$ 関係は相当応力-塑性ひずみ関係であり，本研究で はこの関係を次式による指数型の曲線（Fig.4）で仮定 した.

$$
\tau=\tau_{0}+\left(\tau_{u}-\tau_{0}\right)\left(1-\exp \left(-\frac{E}{\tau_{u}-\tau_{0}} \bar{\varepsilon}_{p}\right)\right)
$$

ここに,

$\tau_{0}$ ：初期降伏曲面に対する相当応力

$\tau_{u}$ : 破壊曲面に対する相当応力
骨材に関しては，本研究で論ずる応力レベルでは弾性 的に挙動するものとし, 破壊曲面はChen らのモデルに 従うと仮定した。

クラックに対しては, 有限要素内に連続的なクラック が発生するという Smeared Cracking Model ${ }^{8}$ を用いた。

また，骨材とモルタル域の有限要素として定ひずみ三 角形要素を用いた。

\section{（3） 界面のモデル化}

弱点部となることが予想される界面には，Goodman らのジョイント要素 ${ }^{6}$ を用いた. またダイレイタンシーの 影響も考慮できるように，構成式にはモール・クーロン 規準を塑性ポテンシャルおよび降伏関数とした Associated Flow Ruleにより界面のモデル化を行った。 Goodman らのジョイント要素は変位関数が一次式であ り, 骨材とモルタルの有限要素に用いた定ひずみ三角形 要素に適合するものである．また Goodman らは応力成 分として, 直応力成分, 世ん断応力成分, モーメント成 分を取り扱っているが，ここではモーメント成分は考え ないことにした。

一般には, 界面の破壊曲面形式として引張力による破 壊と，せん断力による破壊の 2 つが考えられ，破壊規準

（Fig.5）に達すると界面が破壊したとみなされる．し かしながら，実際のコンクリート中では，せん断応力で 破壊を起こそうとする界面においてダイレイタンシーによ る体積膨張が生じ，その結果，圧縮力が作用し実際には 界面の破壊へと至らないものと考えられる．このような 現象を表現でき得るモデルとして，モルタルの場合と同

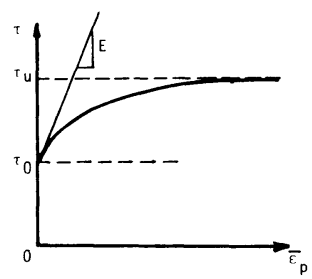

Fig. 4 Proposed Relation Between Equivalent Stress and Plastic Strain.

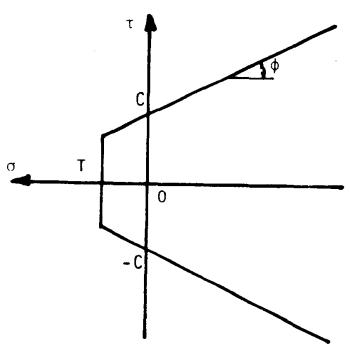

Fig. 5 Mohr-Coulomb Failure Criterion with Tension Cutoff 
様な塑性理論に基づくモデル化を行うことにした．本研 究では，モール・クーロン規準を塑性ポテンシャルおよ び降伏関数とした Associated Flow Rule を用い，塑性 流れの間，応力状態はモール・クーロン規準上を移動す るものとして,ダイレイタンシーの影響を構成式の中に取 り入れた。ここで，材料のひずみ硬化は考えていない。 界面の破壊規準は，引張に対して Tension Cutoffによ り，また塑性流れを起こした界面に対しては，直応力が モルタルの一軸圧縮強度に達すると破壊を起こすものと した。

具体的に, 次式を降伏関数とした.

$f=\tau^{2}-(C-\sigma \tan \varphi)^{2}$

ここで, $f<0$ の場合では降伏曲面内であり, 材料は 弾性的に挙動するものとし， $f=0$ で塑性流れを起こす ものとした. Associated Flow Ruleにより, 塑性ひず み增分 $d \varepsilon_{p}$ は次式で与えられる.

$$
d \varepsilon_{p}=d \lambda \frac{\partial f}{\partial \sigma}
$$

Fig. 6 に示すように，応力軸に対応するひずみ軸を想定 した場合，式( 7 )は，塑性ポテンシャルとみなした降伏 関数に塑性ひずみ増分ベクトルが直交することを意味 し, $\varphi=0^{\circ}$ でない限りダイレイタンシーの影響を構成式に 組み入れることができる. 本研究で用いる $\varphi=37^{\circ}$ は, 文献 9$)$ によるコンクリートの摩擦角 $\varphi$ の值である。応 力成分としては, 直応力 $\sigma$ とせん断応力 $\tau$ の 2 つだけ であるから，応力ベクトルは次式となる。

$$
\{\sigma\}=\{\tau, \sigma\}^{T}
$$

したがって Flow Vector として次式が得られる.

$$
\left\{\frac{\partial f}{\partial \sigma}\right\}=\left[2 \tau,-2 \sigma \tan ^{2} \varphi+2 C \tan \varphi\right]
$$

また, 前述したようにひずみ硬化は考えていないので, 塑性理論からスカラー量 $d \lambda$ は次式となる.

$$
d \lambda=\frac{\left\{\frac{\partial f}{\partial \sigma}\right\}^{T}[D]}{\left\{\frac{\partial f}{\partial \sigma}\right\}^{T}[D]\left\{\frac{\partial f}{\partial \sigma}\right\}}\{d \varepsilon\}
$$

よって, 降伏曲面上での増分応力ーひずみ関係は次式で

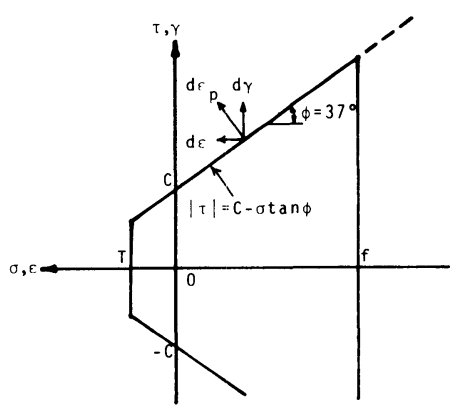

Fig. 6 Failure and Yield Surface for Interface.
表わされる.

$$
\{d \sigma\}=\left|[D]-\frac{[D]\left\{\frac{\partial f}{\partial \sigma}\right\}\left\{\frac{\partial f}{\partial \sigma}\right\}^{T}[D]}{\left\{\frac{\partial f}{\partial \sigma}\right\}^{T}[D]\left\{\frac{\partial f}{\partial \sigma}\right\}}\right|\{d \varepsilon\}
$$

ここで, $[D]$ は, 弾性応カーひずみ関係マトリックス であり次式で表わされる.

$$
[D]=\left[\begin{array}{cc}
K_{\tau} & 0 \\
0 & K_{\sigma}
\end{array}\right]
$$

式(9), 式(12)を式(11)に代入すれば, ダイレイタン シーを考虑した増分応力ーひずみ関係マトリックスが得 られる.

\section{（4）解析方法}

解析は一軸載荷と二軸比例載荷 $\left(\sigma_{1} / \sigma_{2}=-1 /-1, \sigma_{1}\right)$ $\left.\sigma_{2}=-1 /-0.5\right)$ について行い, 一軸載荷に対して変位 増分解析, 二軸載荷に対しては荷重増分解析により解析 を行った。それぞれの増分ステップにおいて各要素の状 態を調へ，もし破壊を起こした要素があれば応力解放を 行い, 解放力による他の要素の破壊がなくなるまでこれ を繰り返した．また解放節点力および増分外力を付加す る前に, 各要素は塑性流れを起こすのか, それとも降伏 曲面内に入ろうとするのかを調べた後に各要素の剛性を 決定した。なお，連立一次方程式の解法として共役傾斜 法を用いた。

\section{3. 数值解析結果}

Fig. 1 に示した 4 ケースについて，一軸載荷と二軸比 例載荷の数值実験を行った. 解析で用いる骨材とモル夕 ルの特性は 4. ( 2 )の実験によって求められた諸定数を 用いた。

数値計算において, 荷重載荷点での荷重-変位曲線は, 各骨材-モルタル平面モデルでの骨材含有率を $48 \%$ と一 定にしたため, 各ケースの間ではほとんど相違がみられ ない.そこで，ここでは骨材-モルタル平面モデルの解

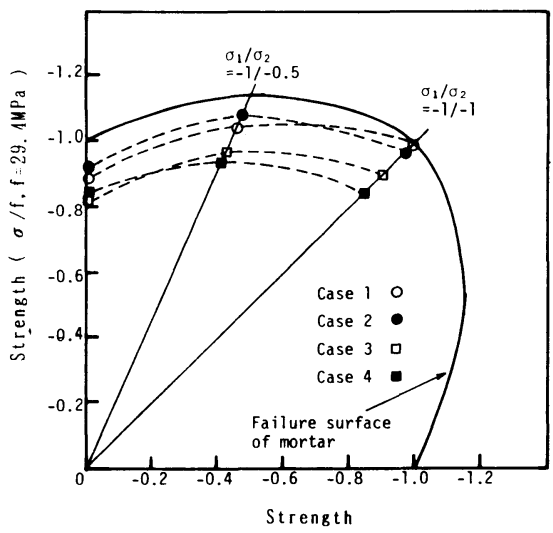

Fig. 7 Strength by Theoretical Analysis. 
析強度と内部応力状態に関する考察を行った. 各ケース の解析強度の比較を Fig. 7 に示す.

\section{（1）－軸戴荷}

解析において Fig. 6 の界面の特性で降伏規準パラメー 夕ー $C$ と引張強度 $T$ を $\left(4.4 \mathrm{MPa}\left(45 \mathrm{kgf} / \mathrm{cm}^{2}\right), 3.4\right.$ $\left.\mathrm{MPa}\left(35 \mathrm{kgf} / \mathrm{cm}^{2}\right)\right), \quad\left(5.9 \mathrm{MPa}\left(60 \mathrm{kgf} / \mathrm{cm}^{2}\right), 4.4\right.$ $\left.\mathrm{MPa}\left(45 \mathrm{kgf} / \mathrm{cm}^{2}\right)\right)$ と変化させて比較を行った.

$(C, T)=\left(4.4 \mathrm{MPa} \quad\left(45 \mathrm{kgf} / \mathrm{cm}^{2}\right), \quad 2.9 \mathrm{MPa} \quad(30\right.$ $\left.\left.\mathrm{kgf} / \mathrm{cm}^{2}\right)\right)$ の場合, 丸い骨材 (Case 1 とCase 2) では, 荷重 $21.6 \mathrm{MPa}\left(220 \mathrm{kgf} / \mathrm{cm}^{2}\right)$ で Fig. 8 のように界面 で塑性流れを生じている.しかしながらダイレイタンシー の影響を本解析のようにモデル化した場合，解析では界 面から破壊せず，モルタルからのクラック破壊により， Case 1 では荷重 $25.5 \mathrm{MPa}\left(260 \mathrm{kgf} / \mathrm{cm}^{2}\right)$ で, Case 2 では荷重 $26.5 \mathrm{MPa}\left(270 \mathrm{kgf} / \mathrm{cm}^{2}\right)$ で破壊へと至った。 隅角部を有する骨材（Case 3 とCase 4) では，荷重 $21.6 \mathrm{MPa}\left(220 \mathrm{kgf} / \mathrm{cm}^{2}\right)$ で Fig. 8 のように隅角部から のクラックを生じており, 界面での塑性流れはほとんど みられず, Case 3 では荷重 $24.5 \mathrm{MPa}\left(250 \mathrm{kgf} / \mathrm{cm}^{2}\right)$ で, Case 4 では荷重 $24.0 \mathrm{MPa}\left(245 \mathrm{kgf} / \mathrm{cm}^{2}\right)$ で破壊に至っ た.
$(C, T)=\left(5.9 \mathrm{MPa} \quad\left(60 \mathrm{kgf} / \mathrm{cm}^{2}\right), \quad 4.4 \mathrm{MPa} \quad(45\right.$ $\left.\left.\mathrm{kgf} / \mathrm{cm}^{2}\right)\right)$ の場合の解析では $(C, T)=(4.4 \mathrm{MPa}(45$ $\left.\left.\mathrm{kgf} / \mathrm{cm}^{2}\right), 3.4 \mathrm{MPa}\left(30 \mathrm{kgf} / \mathrm{cm}^{2}\right)\right)$ のときよりも高い 荷重で界面での塑性流れを生じ始めたが，骨材一モル夕 ル平面モデルの全体的な挙動と解析強度にはほとんど変 化はみられなかった。

以上をまとめると,ダイレイタンシーの影響を本研究の ようにモデル化して考えた場合, 界面が弱点部之ならず, それよりも，骨材の形と配置が骨材-モルタル平面モデ ルの破壊荷重に及ぼす影響は大きいものとなった。

\section{（2）二軸比例就荷}

Fig. 9 に示す $\sigma_{1} / \sigma_{2}=-1 /-1$ の比例載荷では, 骨材モルタル平面モデルとしては面内方向にせん断応力がか からない状態であり，内部応力状態をみるとあたかも骨 材に水圧がかかっているように，圧縮主応力方向がいず れの場合も骨材に垂直方向に向いている．また，Fig.7 に示すように，半径の大きい骨材 (Case 1) よりも半径 の小さい骨材 (Case 2) の場合に, また丸い骨材 (Case 1, Case 2) よりも隅角部を有する骨材 (Case 3, Case 4) の場合に, 解析強度が低くなっている.これは, 応力集 中の影響であると思われる.

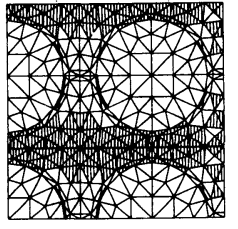

Case 1

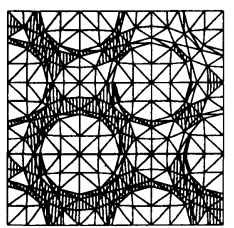

Case 2

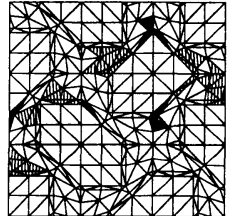

case 3

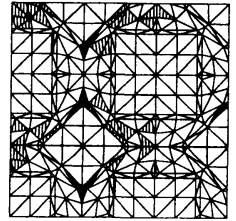

case 4

Dracking area (direction of the crack) Compressive plastic area (direction of the larger compressive

Fig. 8 Internal Stress State Under $\sigma_{1} / \sigma_{2}=-1 / 0$ Axial Loading $(P=21.6 \mathrm{MPa})$.

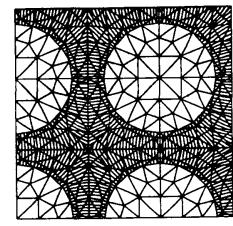

Case 1

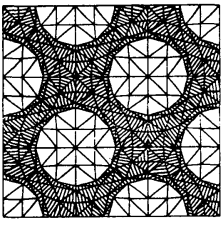

Case 2

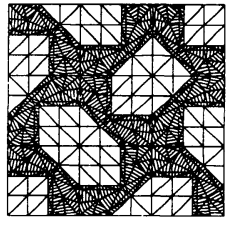

case 3

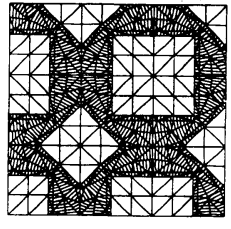

case 4

Fig. 9 Internal Stress State Under $\sigma_{1} / \sigma_{2}=-1 /-1$ Biaxial Loading $(P=19.6 \mathrm{MPa})$.

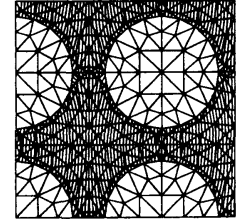

case 1

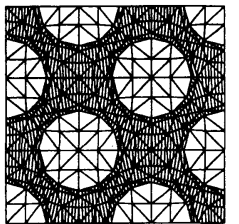

Case 2

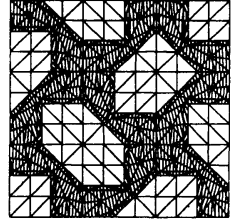

Case 3

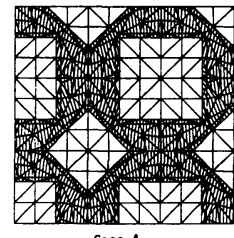

Case 4

Fig. 10 Internal Stress State Under $\sigma_{1} / \sigma_{2}=-1 /-0.5$ Biaxial Loading $(P=25.5 \mathrm{MPa})$. 
Fig. 10 に示す $\sigma_{1} / \sigma_{2}=-1 /-0.5$ の比例載荷では, 骨 材-モルタル平面モデルとしては面内方向にせん断応力 がかかっている状態であり, 静水圧力による影響とせん 断に対する抵抗性が解析強度に反映される. 応力集中の 影響を考えるとCase 3, Case 4 が Case 1, Case 2 より も解析強度の低いのが理解できる. また Case 1 よりも Case 2 の場合に解析強度が高くなったのは，せん断に 対する抵抗性に骨材の配置が関係しているものと考えら れる.これは一軸載荷の場合についてもいえることであ る.

以上に示したように骨材の形状や配置を変えての数値 解析結果から, 平面モデルに作用する静水圧力成分が骨 材の形に関係し, 偏差応力成分が骨材の配置に関係して いることが推測される

\section{4. 載荷実験との比較}

解析の妥当性を検討するために, 解析した骨材-モル

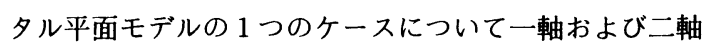
比例載荷試験を行った。

\section{（1）骨材-モルタル平面モデル供試体}

鋼製型枠を作製し，Fig. 1 に示したCase 1 と同じ供 試体（Fig. 11）を作製した。供試体はモルタル打込み後 1 日間湿潤養生し, 26 日間水中養生, その後 1 日間乾 燥させ, 材令 28 日で試験を行った。モルタルプレート 供試体も同様な手順で作製し, モルタルの特性を求めた。 骨材-モルタル平面モデル供試体は 8 個作製し, 一軸載

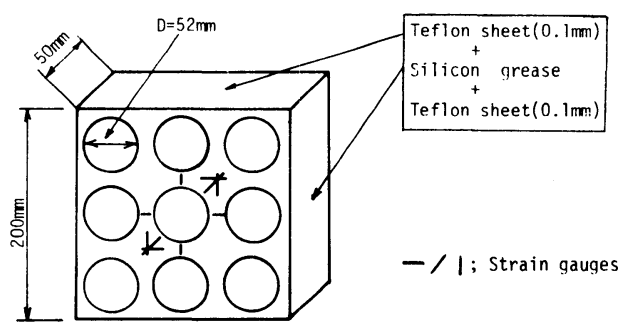

Fig. 11 Specimen of Plane Model in Case 1.
荷に 3 個, $\sigma_{1} / \sigma_{2}=-1 /-1$ の比例載荷に 3 個, $\sigma_{1} / \sigma_{2}=$ $-1 /-0.5$ の比例載荷には 2 個を用いた。また供試体の 載荷面にはテフロンシートを貼り，その上にシリコング リースをぬり，さらにテフロンシートを重ね，端面での 摩擦をできるだけ小さくした。

\section{（2）骨材とモルタルの特性}

使用したモルタルは, 普通ポルトランドセメントを用 い, 水セメント比 $(W / C) 0.55$, 砂は標準砂を用い砂 セメント比 $(S / C) 2$ で配合を行った. モルタルの特性 を求めるモルタルプレート供試体は 5 個作製し, 一軸載 荷に 3 個, $\sigma_{1} / \sigma_{2}=-1 /-1$ の比例載荷には 2 個, 4 . （4）に示す載荷試験を行った. 試験結果によりモル夕 ルの諸定数として, 一軸圧縮強度 $29.4 \mathrm{MPa}(300$ $\left.\mathrm{kgf} / \mathrm{cm}^{2}\right)$, 等二軸圧縮強度 $29.4 \mathrm{MPa}\left(300 \mathrm{kgf} / \mathrm{cm}^{2}\right)$, 初期接線ヤング率 $24.5 \mathrm{GPa}\left(2.5 \times 10^{5} \mathrm{kgf} / \mathrm{cm}^{2}\right)$, ポア ソン比 0.19 を得た。また一軸圧縮および二軸圧縮でそ れぞれの強度の 0.5 倍から圧縮塑性域に入るとみなし, 式( 5 )の相当応力ーひずみ関係において定数 $E$ はモル夕 ルの等二軸載荷試験から得られた相当応力-塑性ひずみ 関係より $E=19.6 \mathrm{GPa}\left(2.0 \times 10^{5} \mathrm{kgf} / \mathrm{cm}^{2}\right)$ とした.引 張強度は元来引張試験により求めるべきものであるが, 解析では圧縮強度の 0.15 倍を用いた.

使用した石材はみかげ石であり, 特性を求めるために シリンダー供試体 $(\phi 50 \times 100 \mathrm{~mm}) 6$ 個をコアカッター で切り出し, 一軸圧縮試験に 3 個, 割裂試験に 3 個用い た. 試験結果より骨材の諸定数として, 一軸圧縮強度 $147 \mathrm{MPa} \quad\left(1500 \mathrm{kgf} / \mathrm{cm}^{2}\right)$, 引張強度 $8.0 \mathrm{MPa}(82$ $\left.\mathrm{kgf} / \mathrm{cm}^{2}\right)$, ヤング率 $52.9 \mathrm{GPa}\left(5.4 \times 10^{5} \mathrm{kgf} / \mathrm{cm}^{2}\right)$, ポ アンン比 0.15 を得た.

\section{（3）界面の特性}

Fig. 6 で降伏規準としたモール・クーロン規準の定数 $C$ を決定するために, Fig. 12 のような押抜き試験を供 試体 3 個について行い, その結果 $C=3.7 \mathrm{MPa}(38$ $\left.\mathrm{kgf} / \mathrm{cm}^{2}\right)$ を得た。 なお引張強度 $T$ についての試験は現 在のところ困難であることから, 試験は行わず, 文献 10)

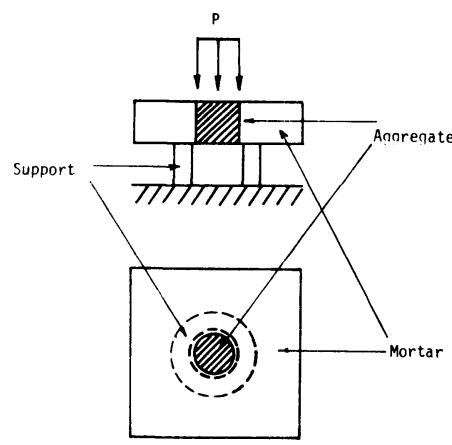

Fig. 12 Punching Shear Test.

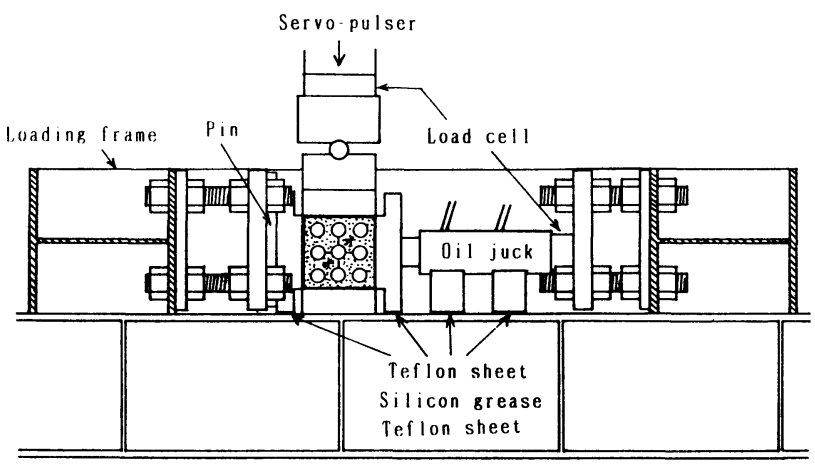

Fig. 13 Biaxial Loading System for Specimens. 
を参考にして解析では $T=2.9 \mathrm{MPa}\left(30 \mathrm{kgf} / \mathrm{cm}^{2}\right)$ を用 いた。

降伏規準としての目安の值である定数 $C$ は, Fig. 12 の押抜きのように, ダイレイタンシーを起こす原因となる 拘束力がない場合の界面付着力とした.このような界面 の付着力を決定するのはたいへん難しい問題であるが, ここでは最大押抜力を周面積で割った值とした.

\section{（4）一軸载荷試験および二軸载荷試験}

本研究では, Fig. 13 に示すように上下方向には $40 \mathrm{t}$ サーボパルサーを, 水平方向には $40 \mathrm{t}$ 手動オイルジャッ キを用い, 骨材一モルタル平面モデル供試体およびモル タルプレート供試体の一軸載荷試験と二軸載荷試験を 行った.二軸載荷は二軸比例載荷で行い, 載荷面ではシ リコングリースとテフロンシートにより端面摩擦の影響 を小さくした.

また，偏心載荷をできるだけ小さくするために試験的 に小さな荷重をかけ，供試体に貼ったひずみゲージ（モ ルタルプレート供試体では計 8 個, 骨材-モルタル平面 モデル供試体では計 20 個）の值により, 偏心ができる だけ小さくなるように供試体を設置した.

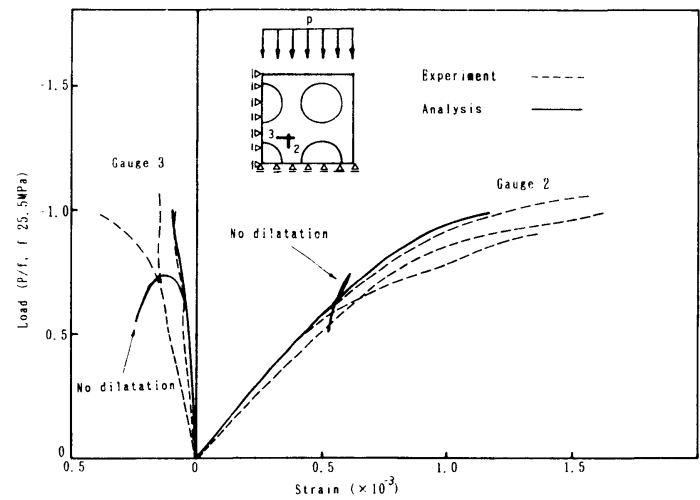

(a) Gauge 2, 3

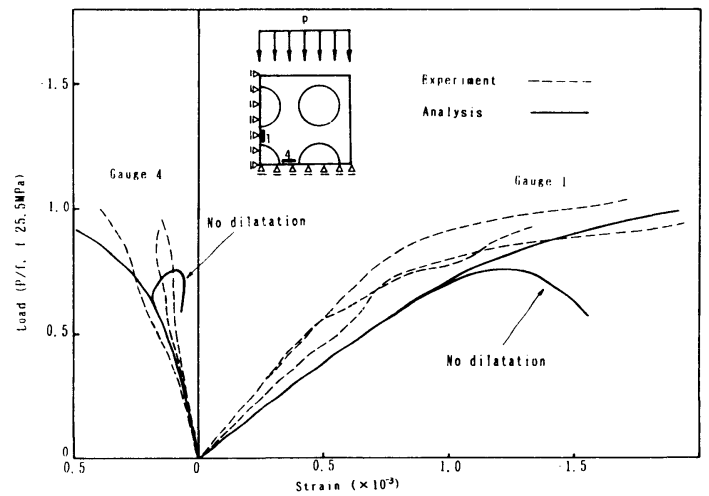

(b) Gauge 1, 4

Fig. 14 Comparison Between Analysis and Experiments on Internal Strains $\left(\sigma_{1} / \sigma_{2}=-1 / 0\right)$.
なお塑性域でのひずみの測定は, ひずみ速度が 25 $\mu / \min$ 以下におさまったときの值である。

\section{（5）実験と解析との比較}

実験と解析との比較はFig. 14 Fig. 16 に示す内部ひ ずみに関して行った。なお, プロットした値は, 供試体 に貼りつけたゲージのうち裏表対角の 4 個のゲージの平 均值である。一軸載荷に対しては, 界面の取扱いにおい てダイレイタンシーの影響を考虑しない Fig. 5 のような Tension Cutoff を伴うモール・クーロン破壊規準を用 いた場合の解析結果についても比較を行った.

Fig. 14 (a) 〜 Fig. 16 (a) は, 骨材から離れた位置 (Gauge 2, Gauge 3) での解析結果と実験結果との比 較であり, Fig. 14(b)〜Fig.16 (b) は骨材と骨材との距 離が最も狭い位置 (Gauge 1, Gauge 4) での比較である.

Fig. 14 (a)〜Fig. 16 (b)はよい一致を得ている.

一軸載荷の実験では, 荷重 $15.7 \mathrm{MPa}\left(160 \mathrm{kgf} / \mathrm{cm}^{2}\right)$ でダイレイタンシーを起こす原因となる拘束がきわめて弱 い側面（Fig.11, 面内方向自由端）において局部的な破 壊が生じたが, それが平面モデルの破壊へとは結びつか ず,平面モデル全体に及ぼす影響は小さなものであった.

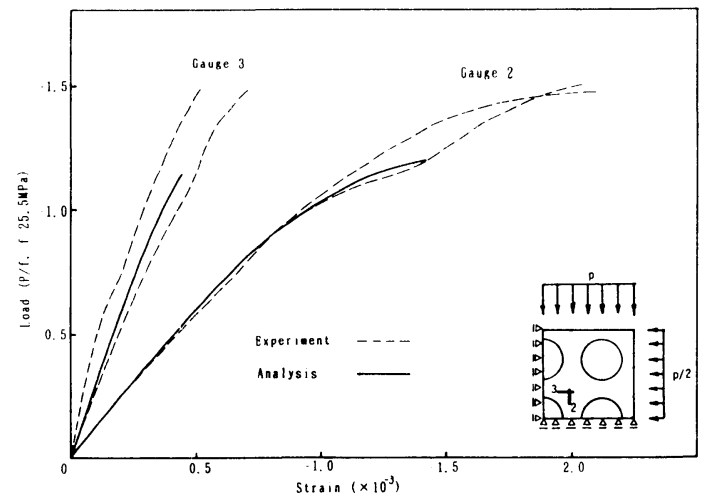

(a) Gauge 2, 3

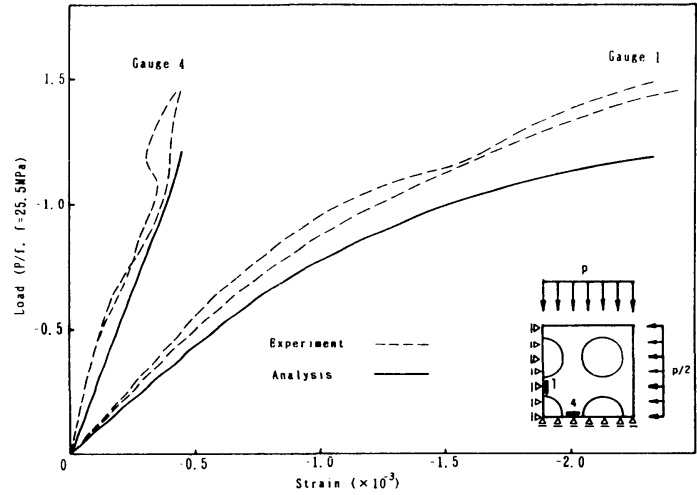

(b) Gauge 1, 4

Fig. 15 Comparison Between Analysis and Experiments on Internal Strains $\left(\sigma_{1} / \sigma_{2}=-1 /-0.5\right)$. 


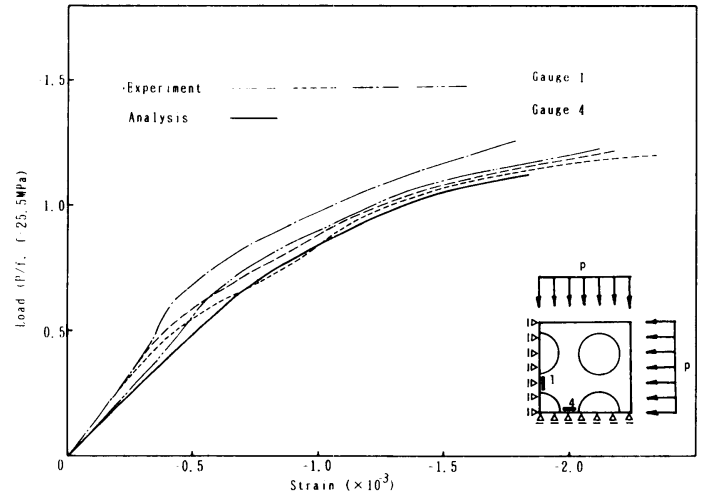

(a) Gauge 2, 3

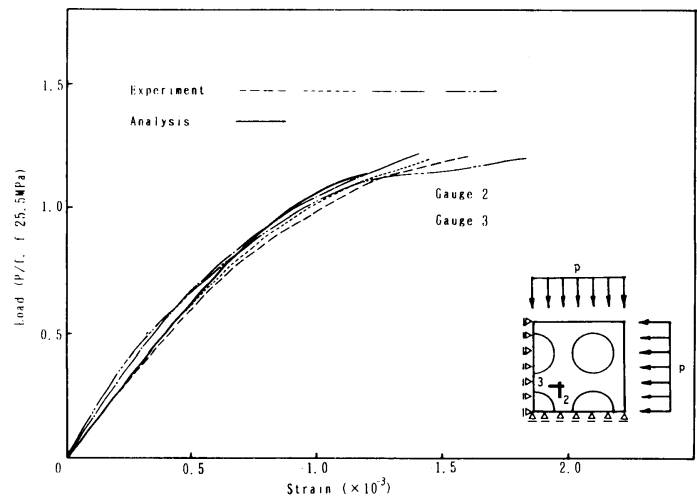

(b) Gauge 1, 4

Fig. 16 Comparison Between Analysis and Experiments on Internal Strains $\left(\sigma_{1} / \sigma_{2}=-1 /-1\right)$.

そして荷重 $25.5 \mathrm{MPa}\left(260 \mathrm{kgf} / \mathrm{cm}^{2}\right)$ 付近で破壊へと 至った. Fig. 14 (a)の一軸載荷の解析值において, ダイ レイタンシーを考慮しない解析の場合は, 実験で局部破壊 を起こした荷重 $15.7 \mathrm{MPa}\left(160 \mathrm{kgf} / \mathrm{cm}^{2}\right)$ で界面の付 着破壊を生じ，荷重 $17.6 \mathrm{MPa}\left(180 \mathrm{kgf} / \mathrm{cm}^{2}\right)$ で平面 モデルは破壊へと至った.ダイレイタンシーを考虑した 場合は，ひずみと破壊荷重はともに実験値をよく追跡し ている.このことにより，ダイレイタンシーを考慮した モデル化の方が適当であるといえる.

Fig. $15(\mathrm{a})$ の $\sigma_{1} / \sigma_{2}=-1 /-0.5$ の比例載荷では，ひ ずみは実験值をよく追跡しているが，破壊荷重は実験值 の方が高いものとなった。この場合の破壊形状は面外方 向の割裂による破壊であり，二次元問題では取り扱えな いものであった．このような現象の原因として，骨材に よる面外方向のひずみ拘束により，骨材にはその方向に 引張力が生じ，また，モルタルではそれ自体の強度が二 次元で論ずるよりも上昇するためであると考えられる.

Fig. $16(\mathrm{a})$ の $\sigma_{1} / \sigma_{2}=-1 /-1$ 比例載荷でも同様なこと がいえる.

Fig. 14(b)～Fig. 16 (b)は解析值がいずれも実験値を
下回り,これは, 応力集中の大きい骨材と骨材との距離 が最も小さい場合で, 変位関数を一次式と仮定する定ひ ずみ三角形要素を相当粗い分割で使用したためであると 考えられる。

以上のように弾性域と塑性域の挙動に関しては, 本研 究において仮定した材料モデルおよび解析方法により, 解析での骨材-モルタル平面モデルの挙動は実際の挙動 とほぼ一致し解析の妥当性が得られた。

破壊荷重に関しては, 一軸圧縮載荷では正確に追跡で きたが，二軸圧縮載荷では実験において破壊点付近で面 外方向の三次元的な力が発生し, 割裂破壊を生じた。し かし, 実験では二軸圧縮載荷の場合, 骨材-モルタル平 面モデルの強度がモルタルの強度を上回ったが, 既往の 研究")によると, 一般にコンクリートの強度はモル夕ル の強度より小さく, 実際のコンクリートでは骨材による モルタルのひずみ拘束の影響は小さいとみなしてよいで あろう. 本研究では骨材モデルとして石材円柱を用いた ことを考えると, 平面応力下でのコンクリートの理想化 として骨材-モルタル平面モデルは，実際のコンクリー トの破壊点付近での挙動を論ずるのには妥当なものであ ると考えられる.

\section{5. あとがき}

解析の妥当性を検討するために, 骨材-モルタル平面 モデルの 1 ケースについて実験と解析との比較を行った 結果, 本研究において仮定した材料モデルおよび解析手 法により, 解析での骨材-モルタル平面モデルの挙動は 弾性域および塑性域を含めての実際の挙動とほぼ一致 し, コンクリートの理想化としての必要条件は満足した. また破壊荷重を論ずる場合にも，平面応力で論ずる限り コンクリートの理想化として本研究による骨材-モル夕 ル平面モデルは適当であることが明確となった．このよ うに妥当性が認められた解析において, 骨材の形状や配 置を変化させて解析を行った結果を平面モデルに作用す る応力成分と結びつけると, 骨材の形状は静水圧成分に 関係し，配置は偏差成分に関係していることが推測され た.

今後, 骨材-モルタル平面モデルの挙動を構成式で扱 われる巨視レベルに結びつけることにより，今まで均質 とみなして有限要素解析を行ってきたコンクリートに不 均一性を導入することが期待でき, 鉄筋とモルタルの界 面の取扱いなどの研究がさらに進めば，コンクリート構 造物に対する解析的研究は実験結果を十分説明し得る強 力な手法となり得るものと確信している.

最後に, 本研究を進めるにあたり, 有益な助言をいた だいた金沢大学複合材料応用研究センター川村満紀教 授，ならびに京都大学防災研究所 (前・金沢大学工学部) 


\section{関口秀雄助教授に感謝いたします。}

\section{参考文献}

1) F.H. ウイットマン・三橋博三訳 : コンクリートの内部 構造と力学的特性, コンクリート工学, Vol. 21, No. 3, pp. 19 30, 1983.

2）前川宏一・岡村 甫：弾塑性破壊モデルに基づくコンク リートの平面応力構成則, コンクリート工学, Vol. 21, No. 5 , pp. $87 \sim 99,1983$.

3）宮本 博·尾田十八・江田祐二 : 鋳鉄の引張り, 圧縮挙 動に及ぼす黒鉛の形状効果, 日本機械学会論文集 (A 編) 45 巻, 389 号, pp. 18 25, 1979.

4) Buyukozturk, O. and Nilson, A.H. : Finite Element Analysis of Plane Concrete with Biaxial Loads, McGill Univ., CSCE, EIC, Finite Element Method in Civil Engineering, pp. 703 728, 1972.

5) Chen, A. C. T. and Chen, W. F. : Constitutive Relation for Concrete, Proc. of ASCE, Vol. 101, No. EM 4, pp. 465 481, 1975.

6) Goodman, R.E, Taylor, R. L. and Brekke, T.L. : A Model for the Mechanics of Jointed Rock, Proc. of ASCE, Vol.94, No. SM 3, pp.637 659, 1968.

7）佐伯 昇・高田宣之・藤田嘉夫：二軸圧縮応力状態のコ ンクリートの変形と破壊挙動, 第 4 回コンクリート工学 年次講演会講演論文集, pp. 181 184, 1982.

8) Chen, W.F. : Plasticity in Reinforced Concrete, McGrow-Hill, 1982.

9) 文献 8 )の p. 302.

10) Avram, C., Făcăoaru, I., Filimon, I., Mîrşe, O. and Tertea, I. : Development in Civil Engineering Vol. 3 Concrete Strength and Strains, ELSEVIER, pp. 129 137, 1981.

(1984. 5.23 - 受付) 